\title{
INFLUENCE OF ARBUSCULAR MYCORRHIZA AND PHOSPHORUS LEVELS ON DRY MATTER PRODUCTION AND NUTRIENTS UPTAKE BY TOMATO SEEDLINGS
}

\author{
M. A. M. Rashid ${ }^{1}$, M. A. H. Chowdhury ${ }^{1}$ and M. A. H. Bhuiyan ${ }^{1}$ \\ Department of Agricultural Chemistry, Bangladesh Agricultural University \\ Mymensingh-2202, Bangladesh
}

\begin{abstract}
To investigate the effects of arbuscular mycorrhiza (AM) and phosphorus (P) rates on the uptake of primary and secondary nutrients by tomato (Lycopersicon esculentum Milli) cV. BARI Tomato-2 seedlings, under P levels ranging from low to excessive, plants were grown in five levels of $\mathrm{P}(0,7.5,15.0,22.5$ and $30.0 \mathrm{mg} \mathrm{P}$ $\mathrm{kg}^{-1}$ soil) as TSP, either inoculated with AM or without AM. The total dry matter yield and uptake of $\mathrm{N}, \mathrm{P}, \mathrm{K}, \mathrm{S}, \mathrm{Ca}$ and $\mathrm{Mg}$ nutrients was significantly influenced by AM inoculation. Nutrient use efficiency in the AM-inoculated seedlings was also significantly higher than that in uninoculated seedlings. The application of different levels of $\mathrm{P}$ lonely increased different nutrients and its uptake positively up to certain level, but at higher level influenced negatively. The N, P, K, S, Ca and $\mathrm{Mg}$ content and uptake all were the highest when $\mathrm{P}$ applied @ $30 \mathrm{~kg} \mathrm{ha}{ }^{-1}$ and the lowest @ 0 kg P ha-1 but uptake found the lowest @ 60 kg P ha-1. There was a significant interaction effect of AM and P levels on nutrients content and their uptakes positively up to certain level, but at higher level of $\mathrm{P}$ combination influenced negatively. Among the treatment combinations, $\mathrm{P}_{30} \times \mathrm{I}$ showed the highest nutrient contents under study and their uptakes but dry matter yield gave the highest value when AM was applied with P @ $15 \mathrm{~kg} \mathrm{ha}^{-1}$.
\end{abstract}

Key words : Arbuscular mycorrhiza, Primary and secondary nutrients, Phosphorus, Tomato

\section{INTRODUCTION}

Phosphorus $(\mathrm{P})$ is one of the essential mineral macronutrients, which is required for maximum yield of agriculturally important crops. Most of the essential plant nutrients, including phosphorus, remain in insoluble form in soil (Abd-Alla, 1994; Yadav and Dadarwal, 1997).

Ironically, soils may have large reserve of total phosphorus, but the amounts available to plants are usually a tiny proportion of this total (Stevenson and Cole, 1999). Most agricultural soils contain large reserves of phosphorus, a considerable part of which has accumulated as a consequence of regular applications of P fertilizers (Richardson, 1994). However, a large portion of soluble inorganic phosphate applied to soil as chemical

\footnotetext{
${ }^{1}$ Senior Scientific Officer (SSO), Soil Science Division, Bangladesh Agricultural Research Institute (BARI), Joydebpur, Gazipur-1701, Bangladesh
} 
fertilizer is rapidly immobilized soon after application and becomes unavailable to plants (Dey, 1988; Singh and Kapoor, 1994; Yadav and Dadarwal, 1997). Farmers are thus asked to apply several-fold excess phosphorus fertilizers in order to overcome this problem. Therefore, the release of insoluble and fixed forms of phosphorus is an important aspect of increasing soil phosphorus availability.

Tomato ranks third in term of world vegetables production (FAO, 2002). As popular vegetables in Bangladesh, tomato and brinjal has a great potentiality and their demand have been increasing day by day. For production of both quantitively and qualitively vegetables healthy seedlings is one of the important factors affecting growth and yield of crops. Providing the best conditions to seedlings for growth and development is also important. Arbuscular mycorrhizal fungi might help to produce healthy and vigorous seedlings of vegetables, fruits and spices crops. The term mycorrhizae denote "fungus roots". It is a symbiotic association between host plants and certain group of fungi at the root system, in which the fungal partner is benefited by obtaining its carbon requirements from the photosynthates of the host and the host in turn is benefited by obtaining the much needed nutrients especially phosphorus (P), calcium, copper etc., which are otherwise inaccessible to it, with the help of the fine absorbing hyphae of the fungus. The hyphae of arbuscular mycorrhizal fungi penetrate roots and grow extensively between and within living cortical cells, forming a very large and dynamic interface between symbionts. The hyphae also extend from root surfaces into the surrounding soil, binding particles and increasing micro and macro aggregation (Auge, 2001). The synchronization between the two symbiotic systems needs an optimal $\mathrm{P}$ level in the nutrient medium to stimulate the growth, nitrogen fixation and other nutrient uptake and not to slow down the formation of effective mycorrhizal associates. As the information presented in the studies in this area is insufficient, the objective of the study was to evaluate the effectiveness of symbioses between the tomato seedlings and AM fungi (Glomus mosseae and Glomus intraradices) on the uptake of major nutrient and phosphorus assimilation at low and higher soil phosphorus levels.

\section{MATERIALS AND METHODS}

The experiment was conducted at net house in the Department of Agricultural Chemistry of Bangladesh Agricultural University, Mymensingh. The experiment was laid out in a completely randomized design (CRD), with three replicates and ten treatment combinations. Each treatment consisted of five P rates i. e., 0, 7.5, 15.0, 22.5, $30.0 \mathrm{mg} \mathrm{P} \mathrm{kg}^{-1}$ soil (from TSP) in combination with and without AM inoculation. The soil was air dried, pulverized and passed through a $2 \mathrm{~mm}$ sieve. The soil was then sterilized with hot air at $100^{\circ} \mathrm{C}$ for 48 hours. The soil had an initial $\mathrm{pH}$ of 6.8 , organic matter content of $0.68 \%$ (Walkley-Black Method), total nitrogen $0.11 \%$ (Kjedahl Method), potassium 0.13 me/100 $\mathrm{g}$ (Flame Photometer Method) and available phosphorus $31.98 \mu \mathrm{g} \mathrm{g}^{-1}$ soil (Bray No. 2 Method). The VA mycorrhizal fungi inoculants consisting of spores, mycorrhizal root fragments and infected soil was collected from pot cultures of trap of sorghum. A Solanaceae crop tomato (Lycopersicon esculentum Milli) cv. BARI tomato-2 was used as the test species. Seeds were treated with hot water at $80^{\circ} \mathrm{C}$ for five minutes and soaked over 
night. In the AM inoculated treatment a hole of about $3 \mathrm{~cm}$ depth and fifty grams of mixed AM inoculum was used in the seed furrows. The seed was seeded at the centre of the hole above the inoculum layer. Watering and other cultural operation were done regularly as when necessary. The plants were harvested at 35 days after germination. Weights of the plants with attached roots and without roots were taken immediately after harvesting. The harvested plants were then dried in the sun for few days and oven dried for 72 hours until moisture content reaches to minimum condition. The dried materials of each treatment was weighed and stored for chemical analysis. The whole plant (all leaves, stem and roots) was processed for chemical analysis. The samples were ground and approximately $1 \mathrm{~g} /$ sample was used for chemical analysis. Wet oxidation method (using $\mathrm{HNO}_{3}: \mathrm{HClO}_{4}=2: 1$ ) was used to digest the samples (Jackson, 1973). The digest sample was subsequently analyzed for total $\mathrm{N}, \mathrm{P}, \mathrm{K}, \mathrm{Ca}, \mathrm{Mg}$ and $\mathrm{S}$ contents and their uptake following standard method (Jackson, 1973). The data were analysed using the appropriate statistical tools.

\section{RESULTS AND DISCUSSION}

\section{Dry matter yield}

There was a highly significant response of mycorrhizal inoculant on total dry matter yield plant $^{-1}$ (Fig. 1). Inoculated plant gave higher $\left(848 \mathrm{mg}\right.$ seedling $\left.{ }^{-1}\right)$ dry matter yield whereas uninoculated plant gave lower $\left(720 \mathrm{mg}^{2}\right.$ seedling- $\left.{ }^{-1}\right)$ dry matter yield (Fig. 1A). Subramanian et al. (2006) observed that root colonization by the arbuscular mycorrhizal (AM) fungus significantly increased dry matter yield and ultimate increased the production. It was observed from Fig.1B that phosphorus application increased dry matter yield appreciably which became statistically significant at $1 \%$ level of probability. Application of P @ $15 \mathrm{~kg} \mathrm{ha}^{-1}$ produced the highest total dry matter yield (965 mg seedling ${ }^{-1}$ ), which was significantly higher over all other $P$ levels and identical to $P_{30}$. The lowest total dry matter yield $\left(601 \mathrm{mg}\right.$ seedling $\left.{ }^{-1}\right)$ was observed in treatment $\mathrm{P}_{60}$ which was lower than control treatment. The interaction effect of phosphorus $\mathrm{x}$ AM inoculant application total dry matter yield was statistically significant. Mycorrhizal inoculant when applied with P @ $15 \mathrm{~kg} \mathrm{ha}^{-1}$ produced the highest dry matter yield (1163 mg seedling ${ }^{-1}$ ). The lowest dry matter yield (552 mg seedling ${ }^{-1}$ ) was observed in $\mathrm{P}_{0} \times \mathrm{U}$ treatments (Fig. 1A). Nogueira et al. (2006) worked on plant growth in mycorrhizal seedlings under different levels of phosphorus ranging from low to excessive. They reported that plants were grown well and dry weight increased by AM inoculation with low level of $P$.

\section{Nitrogen content and uptake}

The $\% \mathrm{~N}$ content and $\mathrm{N}$ uptake by tomato seedling varied significantly due to the effect of AM inoculation (Table 1). The \% $\mathrm{N}$ content and $\mathrm{N}$ uptake of tomato $\mathrm{cv}$. BARI Tomato- 2 seedling obtained from the inoculated treatment was $1.03 \%$ and $8.91 \mathrm{mg}$ seedling ${ }^{-1}$, respectively and that from the uninoculated treatment was $0.75 \%$ and $5.40 \mathrm{mg}^{2}$ seedling-1. The inoculation of arbuscular mycorrhiza induced increased \% $\mathrm{N}$ content and $\mathrm{N}$ uptake in tomato seedlings both were significant at $1 \%$ level of probability. Subramanian et al. 
(2006) studied with inoculated mycorrhiza $(\mathrm{M}+)$ and non-inoculated mycorrhiza (M-) on tomato seedlings. They found that mycorrhizal plants had significantly higher uptake of $\mathrm{N}$ both by roots and shoots. Results presented in Table 2 showed that $\% \mathrm{~N}$ content and $\mathrm{N}$ uptake by tomato seedling was significantly varied and progressively increased by $\mathrm{P}$ application as compared with control treatment up to a certain level. The highest $\mathrm{N}$ content $(1.18 \%)$ and $\mathrm{N}$ uptake $\left(11.01 \mathrm{mg}\right.$ seedling-1) was noted in $\mathrm{P}_{30}$ treatment. The second highest $\mathrm{N}$ content $(0.95 \%)$ and $\mathrm{N}$ uptake $\left(8.05 \mathrm{mg}\right.$ seedling $\left.{ }^{-1}\right)$ was found from the treatment $\mathrm{P}_{45}$ and $\mathrm{P}_{15}$, respectively. The lowest $\mathrm{N}$ content $(0.70 \%)$ and $\mathrm{N}$ uptake $(4.73 \mathrm{mg}$ seedling-1) was found in $\mathrm{P}_{0}$ and $\mathrm{P}_{60}$ treatments respectively. Inoculation of $\mathrm{AM}$ and $\mathrm{P}$ interaction was statistically insignificant on $\mathrm{N}$ content but it was significant on $\mathrm{N}$ uptake (Table 3). Application of $\mathrm{P}_{30} \times \mathrm{I}$ treatment showed the highest $\mathrm{N}$ content $(1.51 \%)$ and $\mathrm{N}$ uptake (15.33 mg seedling-1). The lowest $\mathrm{N}$ content $(0.65 \%)$ and $\mathrm{N}$ uptake (4.39 $\mathrm{mg}$ seedling ${ }^{-1}$ ) was recorded in treatment $\mathrm{P}_{0} \times \mathrm{U}$. In all the $\mathrm{AM}$ and $\mathrm{P}$ combinations, increasing level of $\mathrm{P}$ showed an increasing effect of both $\mathrm{N}$ content and uptake in tomato seedling but the increasing level of $\mathrm{P}$ after $\mathrm{P}_{30} \times \mathrm{I}$ treatment had a decreasing effect of $\mathrm{N}$ content and uptake.

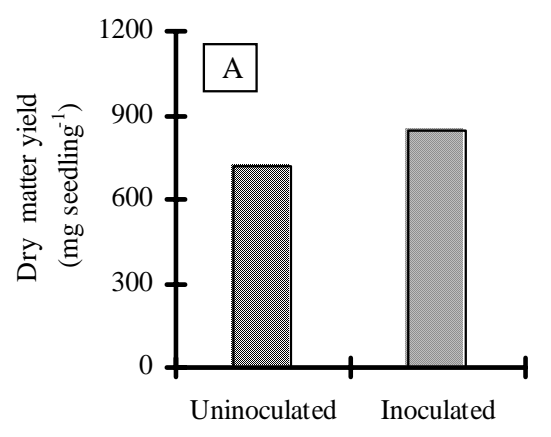

AM inoculants
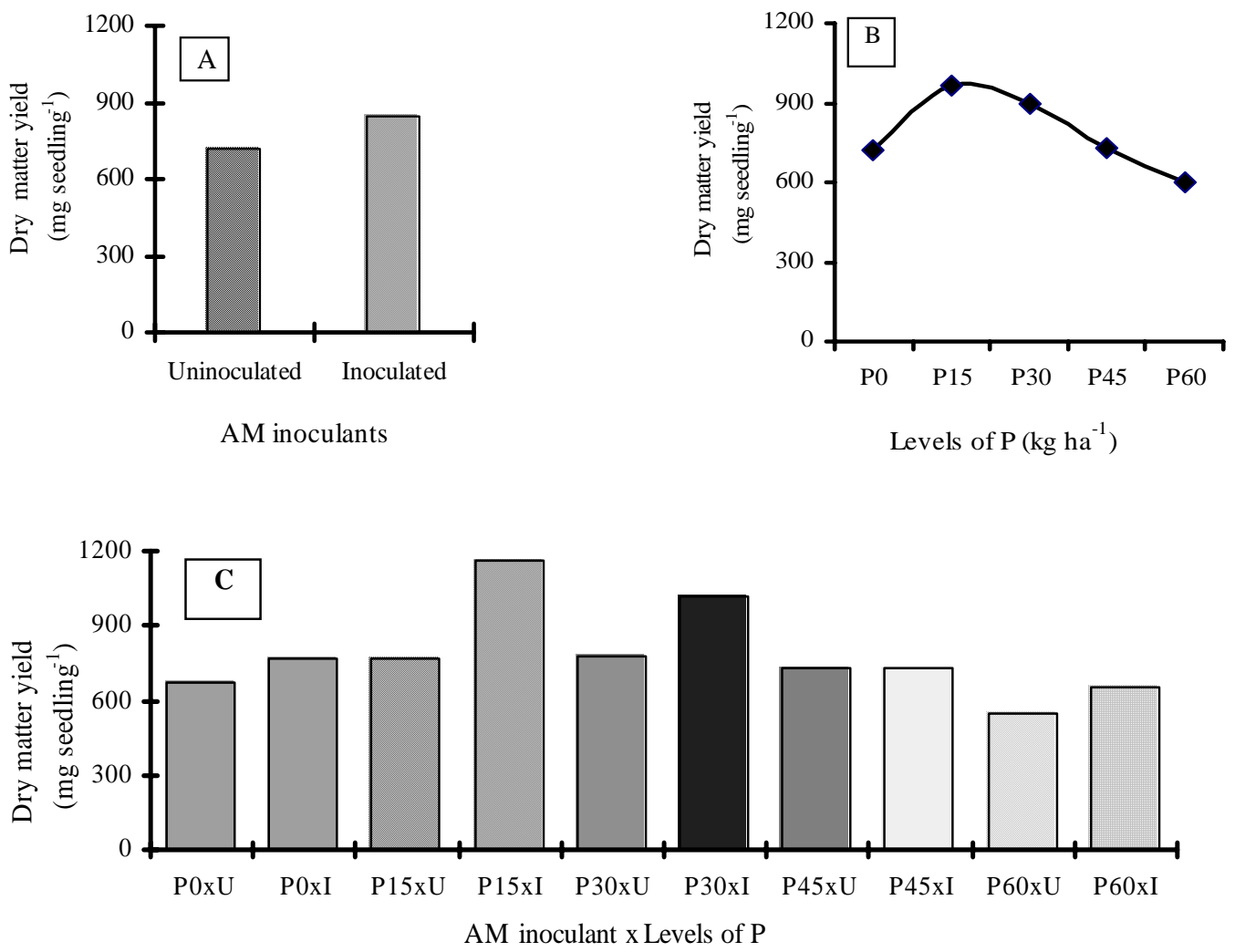

Fig.1 Effect of AM (A), P (B) and their interaction (C) on total dry matter yield of tomato cv. BARI tomato-2 seedlings. 

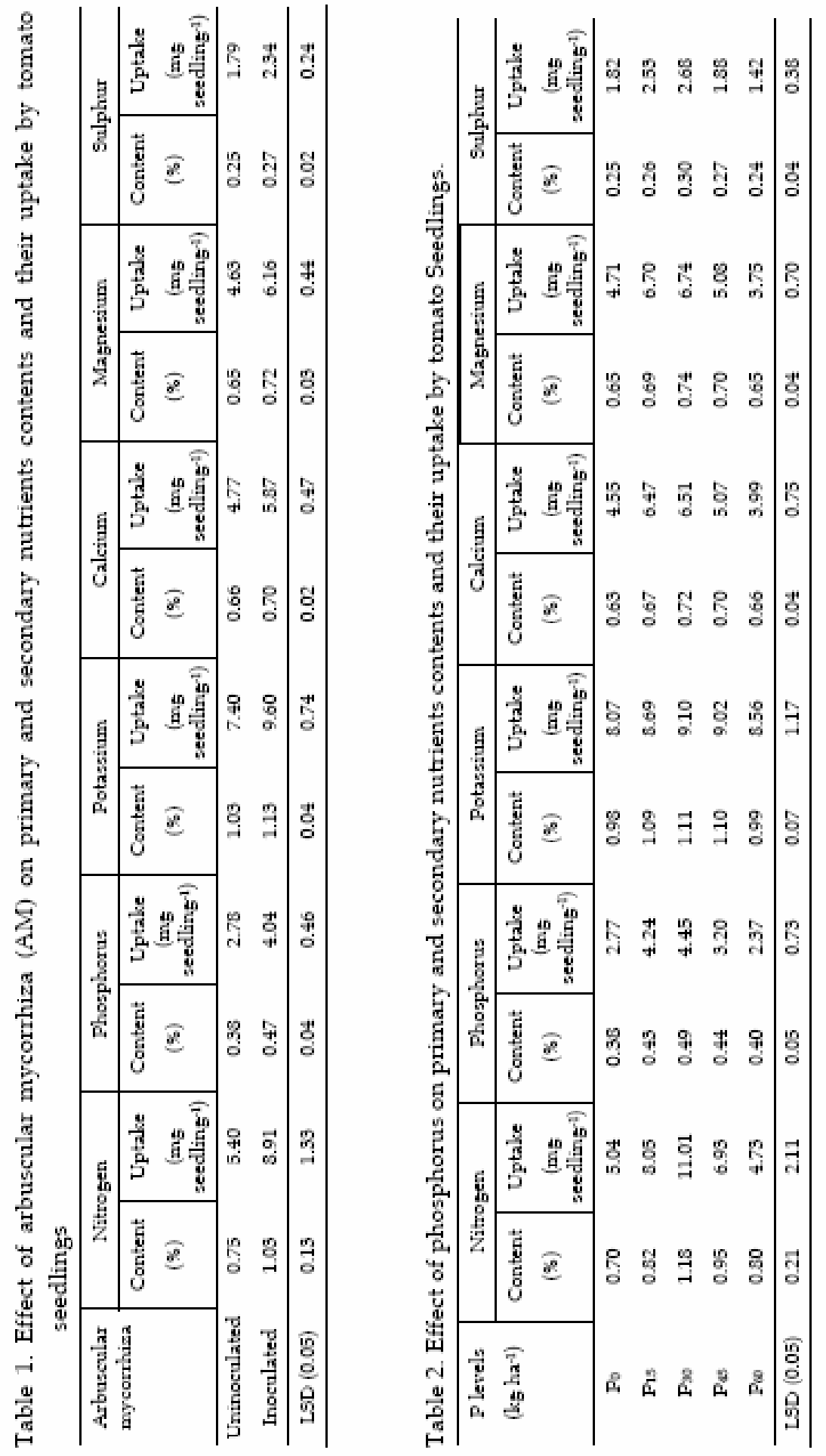


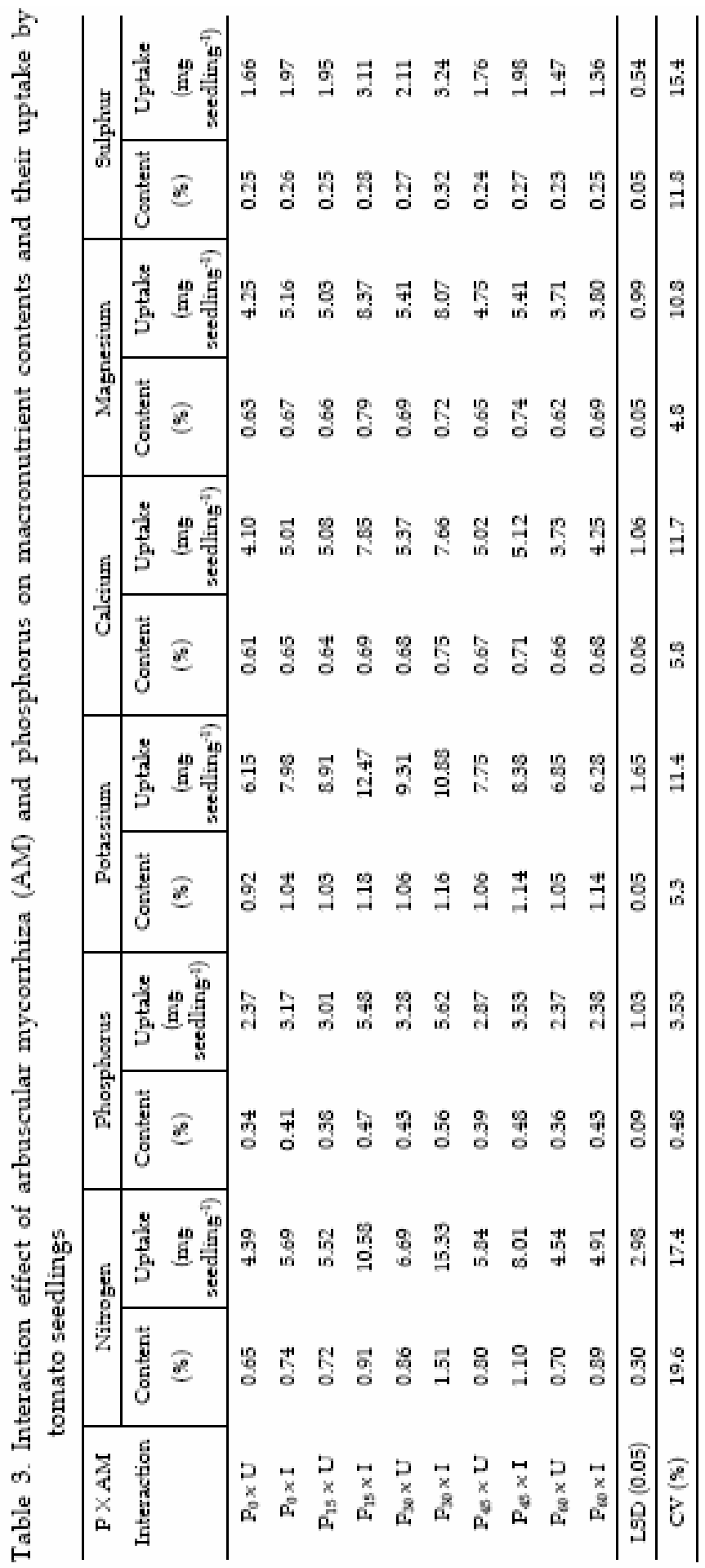




\section{Phosphorus content and uptake}

Arbuscular mycorrhiza inoculation had significant variation in relation to P content and uptake. Data presented in Table 1 showed that variation was higher in AM inoculation than the uninoculated plant. The higher P content $(0.47 \%)$ and uptake (4.04 mg seedling-1) was found in inoculated plant and the lower P content $(0.38 \%)$ and uptake $(2.78 \mathrm{mg}$ seedling-1 ${ }^{-1}$ was also found in uninoculated plant, respectively. Antunes et al. (2007) observed that the arbuscular mycorrhizal fungus Glomus intraradices actively mobilized P from phosphates and predicted that roots inoculated with G. intraradices would take up more $\mathrm{P}$ than those uninoculated. The content and uptake of $\mathrm{P}$ in tomato seedling was significant due to different levels of $\mathrm{P}$ application (Table 2). Among the treatments, the highest $\mathrm{P}$ content $(0.49 \%)$ and uptake $\left(4.45 \mathrm{mg}\right.$ seedling $\left.{ }^{-1}\right)$ were observed at $\mathrm{P}_{30}$ treatment, which was statistically similar with $\mathrm{P}_{45}$ for $\mathrm{P}$ content and with $\mathrm{P}_{15}$ for P uptake. Interaction effect of AM x level of $\mathrm{P}$ was found significant for $\mathrm{P}$ content and uptake. The highest $\mathrm{P}$ content $(0.56 \%)$ and uptake $\left(5.62 \mathrm{mg}\right.$ seedling $\left.{ }^{-1}\right)$ was found in treatment $\mathrm{P}_{30} \times \mathrm{I}$. This result of $\mathrm{P}$ uptake was statistically identical with $\mathrm{P}_{15} \times \mathrm{I}$ treatment. In contrast, the lowest $\mathrm{P}$ content $(0.34 \%)$ and uptake $\left(2.37 \mathrm{mg}\right.$ seedling- $\left.{ }^{-1}\right)$ was observed at treatment $\mathrm{P}_{0} \times \mathrm{U}$ (Table 3). From this result, it was evident that both mycorrhizal inoculation and P level accelerated the accumulation of $\mathrm{P}$ up to certain level and there fore decreased in tomato seedlings. Olsen et al. (1999) studied the effect of a network on mycorrhizae with five rates of applied phosphorus. They reported that the higher concentrations of $\mathrm{P}$ were noted in the youngest mature leaf of VAM $+\mathrm{P}$ level. This finding confirmed the importance of VAM to the enhanced P nutrition at low P levels.

\section{Potassium content and uptake}

The content and uptake of $\mathrm{K}$ in tomato seedlings significantly increased due to AM inoculation (Table 1). The higher $\mathrm{K}$ content $(1.13 \%)$ and uptake $\left(9.60 \mathrm{mg}^{2}\right.$ seedling $\left.{ }^{-1}\right)$ was recorded when the crop inoculated with AM. The lower K content $(1.03 \%)$ and uptake (7.40 mg seedling $\left.{ }^{-1}\right)$ was produced by no inoculation of AM. The result revealed that the content and uptake of $\mathrm{K}$ increased mostly with the inoculation of AM. Several researchers showed that $\mathrm{K}$ content increased significantly by mycorrhizal inoculation (Marschner and Dell, 1994). The K content in tomato seedlings was statistically significant and K uptake by tomato seedlings was statistically insignificant with different $\mathrm{P}$ levels. The highest $\mathrm{K}$ content $(1.11 \%)$ and uptake $(9.10 \mathrm{mg}$ seedling-1) was obtained when the crop was fertilized with $30 \mathrm{~kg} \mathrm{P} \mathrm{ha}^{-1}$ which was statistically similar to $15 \mathrm{~kg} \mathrm{P}^{-1}$ for K content and the lowest $\mathrm{K}$ content $(1.12 \%)$ and uptake $\left(8.07 \mathrm{mg}\right.$ seedling- $\left.{ }^{-1}\right)$ was found from control (Table 2). From the above findings, it was shown that $\mathrm{K}$ content was greatly affected by $\mathrm{P}$ application. The interaction effect of phosphorus $x$ VAM on K content was not significant but uptake varied significantly (Table 3 ). The highest K content (1.18\%) and uptake (12.47 mg seedling ${ }^{-1}$ ) was recorded when mycorrhizal inoculant was applied with $\mathrm{P}_{15}$ level, which was statistically the best of all. The second highest $\mathrm{K}$ content $(1.16 \%)$ and uptake (10.88 mg seedling $\left.{ }^{-1}\right)$ was recorded in treatment $\mathrm{P}_{30} \times \mathrm{I}$. The treatment $\mathrm{P}_{0} \times \mathrm{U}$ recorded the lowest $\mathrm{K}$ content $(0.92 \%)$ and uptake $\left(6.15 \mathrm{mg}\right.$ seedling $\left.{ }^{-1}\right)$. 


\section{Calcium content and uptake}

It was revealed from Table 1 that VAM inoculation significantly enhanced the Ca content and uptake in tomato $\mathrm{cv}$. BARI tomato- 2 seedlings. The highest Ca content $(0.70 \%)$ and uptake (5.87 mg seedling-1) was found when the crop was inoculated with arbuscular mycorrhiza. While the uninoculated plants showed lower Ca content $(0.66 \%)$ and uptake (4.77 mg seedling-1). Li et al. (2005) studied on the influence of three arbuscular mycorrhizal fungi and phosphorus on growth and nutrient status of taro. Inoculation with AM fungi significantly increased the contents of calcium (Ca). The results showed significant variation in $\mathrm{Ca}$ content and uptake in tomato seedling due to the effect of different levels of $\mathrm{P}$ (Table 2). The treatment $\mathrm{P}_{30}$ accumulate both maximum shoot $\mathrm{Ca}$ content $(0.72 \%)$ and uptake $\left(6.51 \mathrm{mg}\right.$ seedling $\left.{ }^{-1}\right)$, which was statistically superior to other treatments except $\mathrm{P}_{45}$ for Ca content and $\mathrm{P}_{15}$ for Ca uptake. The treatments $\mathrm{P}_{0}$ accumulates minimum $\mathrm{Ca}$ content $(0.63 \%)$ and treatments $\mathrm{P}_{60}$ minimum Ca uptake (3.99 $\mathrm{mg}$ seedling-1).

The treatment combination of AM and levels of $\mathrm{P}$ interaction significantly increased $\mathrm{Ca}$ uptake but there was no significant variation in content in tomato seedlings (Table 3). The highest Ca content (0.75\%) and uptake (7.66 mg seedling $\left.{ }^{-1}\right)$ was achieved in $\mathrm{P}_{30} \times \mathrm{I}$ and $\mathrm{P}_{15}$ $x$ I treatments, respectively which was superior to all other treatments for Ca uptake. The lowest Ca content $(0.61 \%)$ was found from $\mathrm{P}_{0} \times \mathrm{U}$ but lowest uptake (3.73 mg seedling-1) was found from $\mathrm{P}_{60} \times \mathrm{U}$ treatment combination.

\section{Magnesium content and uptake}

Magnesium content and uptake showed significant effect by inoculation with AM (Table 1$)$. The higher $\mathrm{Mg}$ content $(0.72 \%)$ and uptake $\left(6.16 \mathrm{mg}\right.$ seedling $\left.{ }^{-1}\right)$ was produced when the crop was inoculated with mycorrhiza, which was statistically superior to uninoculated. The lower $\mathrm{Mg}$ content (0.65\%) and uptake (4.63 mg seedling-1) was obtained from uninoculated treatment. Magnesium content and uptake differed significantly due to different levels of $\mathrm{P}$ application (Table 2). The highest $\mathrm{Mg}$ content $(0.74 \%)$ and uptake $(6.74 \mathrm{mg}$ seedling-1) was observed when the crop was fertilized with $30 \mathrm{~kg} \mathrm{P} \mathrm{ha-1}$ and the uptake was statistically identical with $15 \mathrm{~kg} \mathrm{P} \mathrm{ha}^{-1}$. The lowest $\mathrm{Mg}$ content $(0.65 \%)$ and uptake $\left(6.74 \mathrm{mg}\right.$ seedling- $\left.{ }^{-1}\right)$ was obtained from $\mathrm{P}_{0}$ and $\mathrm{P}_{60}$, respectively. It can be concluded that increase in P levels caused considerable increase in $\mathrm{Mg}$ content in tomato seedlings.

The results on the interaction effect of inoculation of vesicular arbuscular mycorrhiza and different levels of $\mathrm{P}$ showed that the variation was non significant in $\mathrm{Mg}$ content but the uptake showed significant effect (Table 3). The highest Mg content $(0.79 \%)$ and uptake ( 8.37 mg seedling-1) was produced by $15 \mathrm{~kg} \mathrm{P} \mathrm{ha}^{-1}+\mathrm{AM}$ inoculant. The treatment, $\mathrm{P}_{30} \times \mathrm{I}$ produced the second highest $\mathrm{Mg}$ uptake which was statistically similar to $\mathrm{P}_{15} \times \mathrm{I}$ treatment combinations. Treatment combination $\mathrm{P}_{60} \times \mathrm{U}$ produced the lowest $\mathrm{Mg}$ content $(0.62 \%)$ and $\mathrm{Mg}$ uptake (3.71 $\mathrm{mg}$ seedling- $\left.{ }^{-1}\right)$. 


\section{Sulphur content and uptake}

The content and uptake of $S$ in tomato seedlings was significant due to AM inoculation (Table 1$)$. The higher $S$ content $(0.27 \%)$ and uptake $(2.34 \mathrm{mg}$ seedling-1) were recorded with AM inoculation, and lower S content $(0.25 \%)$ and uptake $(1.79 \mathrm{mg}$ seedling-1) also recorded without AM inoculation. Present results indicated that increasing levels of $S$ was observed by addition of AM inoculant. Different $P$ levels significantly influenced the $\mathrm{S}$ content and uptake in tomato seedlings (Table 2). Application of phosphorus @ $30 \mathrm{~kg}$ ha $^{-1}$ gave the highest $S$ content $(0.30 \%)$ and uptake $\left(2.68 \mathrm{mg}\right.$ seedling $\left.{ }^{-1}\right)$. This was statistically identical to those in $\mathrm{P}_{15}$ and $\mathrm{P}_{45}$ for $\mathrm{S}$ content and similar to those in $\mathrm{P}_{15}$ for $\mathrm{S}$ uptake. The lowest $\mathrm{S}$ content and uptake was recorded in $\mathrm{P}_{60}$ which was $0.24 \%$ and 1.42 mg seedling- ${ }^{-1}$, respectively. Interaction effect of AM and level of P noted that there was a insignificant variation of $S$ content but uptake was significantly varied (Table 3 ). The highest $\mathrm{S}$ content $(0.32 \%)$ and uptake $\left(3.24 \mathrm{mg}\right.$ seedling-1) was recorded in $\mathrm{P}_{30} \times \mathrm{I}$ treatment, which was statistically similar with $P_{15} \times$ I treatment for uptake and the lowest $\mathrm{S}$ content $(0.25 \%)$ and uptake $\left(1.36 \mathrm{mg}\right.$ seedling $\left.{ }^{-1}\right)$ was in $\mathrm{P}_{0} \times \mathrm{U}$ and $\mathrm{P}_{60} \times \mathrm{U}$ treatment, respectively. It was evident from the above discussion that $S$ uptake in tomato seedlings was influenced by AM and P interaction rather than content.

\section{CONCLUSION}

Among the treatment combinations, $\mathrm{P}_{30} \times \mathrm{I}$ showed the highest primary and secondary nutrients contents and their uptakes but dry matter yield gave the highest value when AM was applied with P @ $15 \mathrm{~kg} \mathrm{ha}^{-1}$. The study ventilated that AM use as a biofertilizer for production of tomato seedlings reduced phosphatic fertilizer uses.

\section{REFERENCES}

Abd-Alla, M. H. 1994. Phosphatases and the utilization of organic phosphorus by Rhizobium leguminosarum biovar viceae. Appl. Microbiol., 18: 294-296.

Antunes, P. M., Schneider, K., Hillis, D. and Klironomos, J. N. 2007. Can the arbuscular mycorrhizal fungus Glomus intraradices actively mobilize P from rock Phosphates. Pedobiologia., 51(4): 281-286.

Auge, R. M. 2001. Water relation, drought and VA mycorrhizal simbiosis. Mycorrhiza., 11: 3-42.

Dey, K. B. 1988. Phosphate solubilizing organisms in improving fertility status. In: Sen Biofertilizers: Potentialities and Problems. S.P, Palit, P. eds. Calcutta: Plant Physiology Forum, Naya Prokash., pp. 237-248.

Jackson, M. L. 1973. Soil Chemical Analysis. Prentice Hall of India Pvt. Ltd., New Delhi. pp. 151-154.

Li, M., Liu, R. J., Christie, P. and Li, X. L. 2005. Influence of three arbuscular mycorrhizal fungi and phosphorus on growth and nutrient status of taro. Communications in Soil Sci. and Plant Analysis. 36(17-18): 2383-2396.

Marschner, H. and Dell, B. 1994. Nutrient uptake in mycorrhizal symbiosis. Plant and Soil., 65(3): 89-102. 
Nogueira, M. A. and Cardoso, E.J. B. N. 2006. Plant growth and phosphorus uptake in mycorrhizal rangpur lime seedlings under different levels of phosphorus. Pesquisa Agropecuaria Brasileira., 41(1): 93-99.

Olsen, J. K., Schaefer, J. T., Edwards, D. G., Hunter, M. N., Galea, V. J. and Muller, L. M. 1999. Effects of a network of mycorrhizae on capsicum (Capsicum annuum L.) grown in the field with five rates of applied phosphorus. Australian J. Agric. Res., 50(2): 239-252.

Richardson, A. E. 1994. Soil microorganisms and phosphorus availability. In: Soil Biota, Management in Sustainable Farming Systems, Pankhurst C. E., Doube B. M., Grupta V.V.S.R. and Grace P.R. Eds. Melbourne, Australia: CSIRO. pp. 50-62.

Singh, S. and Kapoor, K. K. 1994. Solubilization of insoluble phosphate by bacteria isolated from different sources. Environ. Ecol., 12: 51-55.

Stevenson, F. J. and Cole, M. A. 1999. Cycles of Soil : Carbon, Nitrogen, Phosphorus, Sulphur, Micronutrients, 2nd Edn. Wiley, USA. p. 427.

Subramanian, K. S., Santhanakrishnan, P. and Balasubramanian, P. 2006. Responses of field grown tomato plants to arbuscular mycorrhizal fungal colonization under varying intensities of drought stress. Scientia Horticulturae., 107(3): 245-253.

Yadav, K. S. and Dadarwal, K. R. 1997. Phosphate solubilization and mobilization through soil microorganisms. In: Biotechnological Approaches in Soil Microorganisms for Sustainable Crop Production. Dadarwal, R. K. ed., Scientific Publishers, Jodhpur, India. pp. 293-308. 